\title{
A New Dolabrane Dinorditerpene from Ceriops tagal
}

\author{
Xin Wu1, Hongbo Liao' ${ }^{*}$, Hongyu Lu ${ }^{3,4}$, Chaohua Zhang ${ }^{3,4}$ \\ ${ }^{1}$ Guangdong Key Laboratory for Research and Development of Natural Drugs, Guangdong Medical University, \\ Zhanjiang, China \\ ${ }^{2}$ Department of Pharmacology, Guangdong Medical University, Zhanjiang, China \\ ${ }^{3}$ Guangdong Provincial Key Laboratory of Aquatic Product Processing and Safety, Guangdong Ocean University, \\ Zhanjiang, China \\ ${ }^{4}$ Key Laboratory of Advanced Processing of Aquatic Products of Guangdong Higher Education Institution, \\ Guangdong Ocean University, Zhanjiang, China \\ Email: "sarahliao@gdmu.edu.cn
}

Received 7 August 2016; accepted 15 August 2016; published 19 August 2016

Copyright () 2016 by authors and OALib.

This work is licensed under the Creative Commons Attribution International License (CC BY). http://creativecommons.org/licenses/by/4.0/

(c) $\underset{\mathrm{EY}}{\mathrm{Br}}$ Open Access

\section{Abstract}

A new dolabrane dinorditerpene, tagalsine $\mathrm{X}(1)$, was isolated from the leaves of Ceriops tagal, along with five known analogues (2-6). Their structures were established on the basis of spectroscopic data or comparison with the literatural data. Their cytotoxic activities against four human carcinoma cell lines (CNE-2, HCT-116, HepG2and A549) were also evaluated, which displayed that only compound 2 had significant cytotoxicity against those cell lines with IC50 values of 13.57, 42.32, 11.21 and $15.23 \mu \mathrm{M}$, respectively.

\section{Keywords}

Ceriops tagal, Dolabrane, Tagalsine X, Cytotoxicity

Subject Areas: Plant Science

\section{Introduction}

The plant Ceriops tagal (Rhizophoraceae), which has been used to treat malaria [1], infected wounds and obstetric and hemorrhagic conditions [2], is the only species of genus Ceriops distributed in southern coastal zone of China [1]. Its previous chemical studies have yielded a series of diterpenoids and triterpenoids [3] with antifouling [4], antifeedant [5] and anticancer [6] activities. In this paper, we reported the isolation and structural eluci-

\footnotetext{
${ }^{*}$ Corresponding author.
} 
dation of a new dolabrane dinorditerpene, tagalsine $\mathrm{X}(\mathbf{1})$, along with five known analogues (2-6), as well as their cytotoxic activities against four human carcinoma cell lines (CNE-2, A549, HepG2 and HCT-116).

\section{Materials and Methods}

\subsection{Plant Material}

The leaves of Ceriops tagal (Figure 1) were collected in Haikou City, Hainan Province of China, and authenticated by Prof. Weidong Han (College of Agriculture, Guangdong Ocean University). A voucher specimen (No. 20130513) was deposited in the Guangdong Key Laboratory for Research and Development of Natural Drugs, Guangdong Medical College, Zhanjiang, China.

\subsection{General}

Human carcinoma cell lines (CNE-2, A549, HepG2 and HCT-116) all came from ATCC. Column chromatographies (CC) were carried out byD101 macroporous resin (Beilianchem, China), silica gel (Qingdaohaiyang, China) and reversed-phase $\mathrm{C}_{18}$ silica gel (YMC, Japan). 1D and 2D NMR spectra were acquired on Bruker AV400 spectrometer.HR-ESI-MS was recorded by an Agilent 6210 LC/MSD TOF mass spectrometer. Analytical high-performance liquid chromatography (HPLC) were carried out on a Agilent 1200 series and a $\mathrm{C}_{18}$ reversedphase column (Cosmosil, $4.6 \mathrm{~mm} \times 250 \mathrm{~mm}, 5.0 \mu \mathrm{m}$ ). Preparative HPLC were carried out on a Gilson 305 pump, a Varian Prostar 345 UV detector and a $\mathrm{C}_{18}$ reversed-phase column (Cosmosil, $20 \mathrm{~mm} \times 250 \mathrm{~mm}, 5.0$ $\mu \mathrm{m})$.

\subsection{Extraction and Isolation}

The air dried leaves of Ceriops tagal (10.0 kg) were powdered and extracted three times (24 h for each) with 95\% EtOH at room temperature $(3 \times 30 \mathrm{~L})$. The tannins were precipitated and filtrated after keeping the solution standing for 48 hours at room temperature. Crude extract (800 g) was yielded by concentrating the filtration under vacuum. The residue was suspended in water, and then partitioned with EtOAc. After removing the solvent, the EtOAc extract (300 g) was separated by D101 macroporous resin column chromatography (CC) using gradient ethanol aqueous solutions ( $60 \%, 80 \%$ and $95 \%$ ) as eluants to give three fractions (A-C). Fraction B ( $80 \%$ ethanol, $100 \mathrm{~g}$ ) was then subjected to silica gel CC eluting with n-hexane-ethyl acetate $(100: 0 \rightarrow 10: 1)$ to yield seven subfractions B1-B7. Subfraction B4 (H:E 9:1, 7.0 g) was chromatographed on ODS column eluting with $\mathrm{CH}_{3} \mathrm{CN}-\mathrm{H}_{2} \mathrm{O}(1: 9 \rightarrow 7: 3)$ to afford eight subfractionsB4a-B4h. $\mathrm{B} 4 \mathrm{~b}\left(\mathrm{CH}_{3} \mathrm{CN}: \mathrm{H}_{2} \mathrm{O}\right.$ 3:7, 0.6 g) was purified repeatedly by prepared HPLC $\left(\mathrm{CH}_{3} \mathrm{CN}: \mathrm{H}_{2} \mathrm{O}\right.$ 4:6) to yield compound 1 (13.0 mg), 2 (14.8 mg), 3 (65.1 mg), 4 (28.3 $\mathrm{mg}), \mathbf{5}(50.1 \mathrm{mg}$ ) and 6 (61.3 mg) (Figure 2).

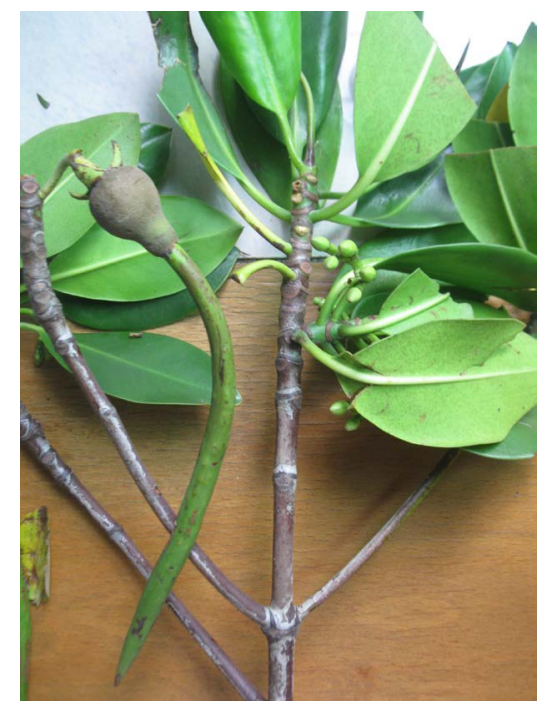

Figure 1. The twigs of $C$. tagal with leaves and fruit. 

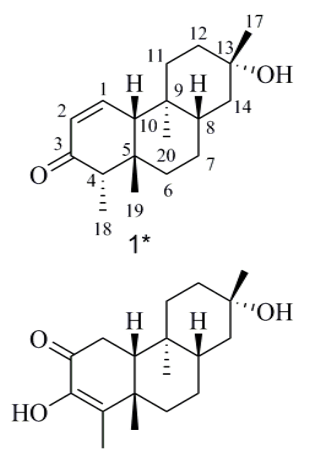

4

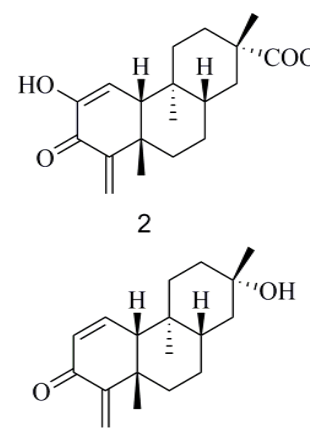

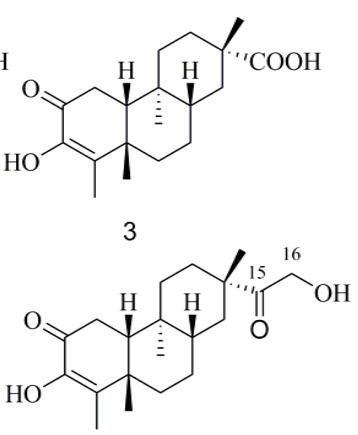

6

Figure 2. The structures of compounds 1-6.

\subsection{Cytotoxicity Assay by MTT Method}

The cytotoxicity effects of compounds 1-6 were tested against four human carcinoma cell lines (CNE-2, A549, HepG2 and HCT-116) by the MTT method as described previously [7]. Generally, the cell suspensions were platedinto 96-well plates and cultured in RPMI-1640 at $37^{\circ} \mathrm{C}$, with $5 \% \mathrm{CO}_{2}$ in incubator overnight. The test compound solutions (in $0.1 \%$ DMSO) at different concentrations were added to the corresponding wells. After exposure for $68 \mathrm{~h}$, MTT was added to each well and the plates were incubated for $4 \mathrm{~h}$. Finally, the supernatant was discarded and $200 \mu \mathrm{L}$ of DMSO was added to the well to dissolve the blue-violet crystal, then the opticaldensity (OD) values were read on the microplate reader at $570 \mathrm{~nm}$. All tests and analyses were carried out in triplicate. DMSO and doxorubicin were applied as the blank control and positive control, respectively.

\section{Results and Discussion}

\subsection{Structure Elucidation}

Compound 1, obtained as pale yellow amorphous powder in methanol, had the molecular formula $\mathrm{C}_{18} \mathrm{H}_{28} \mathrm{O}_{2}$ as established by its HR-ESI-MS at $\mathrm{m} / z 299.1992[\mathrm{M}+\mathrm{Na}]^{+}$(calcd for $\mathrm{C}_{18} \mathrm{H}_{28} \mathrm{O}_{2} \mathrm{Na}$ : 299.1982), which implied that $\mathbf{1}$ had five degrees of unsaturation. The ${ }^{13} \mathrm{CNMR}$ and DEPT-135 spectra of $\mathbf{1}$ displayed a carbonyl carbon, and two olefinic carbons, as well as 15 aliphatic carbons including four methyls, five methylenes, three methines, and three quaternary carbons. The ${ }^{1} \mathrm{HNMRspectrum}$ of 1 showed fourmethyls at $\delta_{\mathrm{H}} 0.87(3 \mathrm{H}, \mathrm{s}), 0.92(3 \mathrm{H}, \mathrm{s})$, $1.03(3 \mathrm{H}, \mathrm{d}, J=5.2 \mathrm{~Hz}), 1.31(3 \mathrm{H}, \mathrm{s})$, a pair of olefinic protons at $\delta_{\mathrm{H}} 6.84(1 \mathrm{H}, \mathrm{dd}, J=10.1,5.9 \mathrm{~Hz})$ and6.13 $(1 \mathrm{H}, \mathrm{d}, J=10.2 \mathrm{~Hz})$, a methine at $\delta_{\mathrm{H}} 2.8(1 \mathrm{H}, \mathrm{dd}, 13.3,6.6)$ and a set of aliphatic protons ranging from $\delta_{\mathrm{H}} 1.22$ to 1.96. The above spectroscopic features revealed that compound $\mathbf{1}$ was a dolabrane-type dinorditerpenoid. The ${ }^{13} \mathrm{C}$ NMR and ${ }^{1} \mathrm{H}$ NMR spectra of compound $\mathbf{1}$ were very similar to those of tagalsin Q (5) [8] except for the positions at 3-5, 18 and 19, which suggested that their B/C rings were the same, while their A rings were different. All the ${ }^{1} \mathrm{H}$ and ${ }^{13} \mathrm{C}$ NMR signals of $\mathbf{1}$ were assigned as shown in Table 1 with the aid of ${ }^{1} \mathrm{H}-{ }^{1} \mathrm{H}$ COSY, HSQC and HMBC experiments. The bond between C-4 and C-18 changed from olefinic double-bond of tagalsin Q (5) into aliphatic single-bond of $\mathbf{1}$, which was further supported by the HMBC correlations between $\mathrm{H}-18\left(\delta_{\mathrm{H}} 1.03\right)$ and C-3 $\left(\delta_{\mathrm{C}} 202.7\right) / \mathrm{C}-5\left(\delta_{\mathrm{C}} 39.0\right)$ (Figure 3$)$. The relative configuration of 1 was proposed on the basis of ROESY correlations (Figure 3). The $\beta$-orientation of $\mathrm{H}-8, \mathrm{H}-10, \mathrm{H}_{3}-19$ and $\mathrm{H}_{3}-17$, and the $\alpha$-orientation of $\mathrm{H}_{3}-18$ and were $\mathrm{H}_{3}-20$ deduced from the presence of ROESY interactions between $\mathrm{H}-8 / \mathrm{H}-6 \beta, \mathrm{H}-6 / \mathrm{H}-10, \mathrm{H}-10 / \mathrm{H}_{3}-19$, $\mathrm{H}-19 / \mathrm{H}_{3}-4, \mathrm{H}-10 / \mathrm{H}-6 / \mathrm{H}, \mathrm{H}-6 / \mathrm{H}-8, \mathrm{H}-10 / \mathrm{H}-8, \mathrm{H}-10 / \mathrm{H}-11 \beta, \mathrm{H}-11 / \mathrm{\beta} / \mathrm{H}-17$ and $\mathrm{H}-18 / \mathrm{H}-6 a$, and the absence of ROESY interactions between $\mathrm{H}_{3}-18 / \mathrm{H}-19, \mathrm{H}_{3}-18 / \mathrm{H}-10, \mathrm{H}_{3}-20 / \mathrm{H}-8$ and $\mathrm{H}_{3}-20 / \mathrm{H}-19$. On the basis of the above results, compound 1 was identified as (4S*, 5S*, 8S*, 9S*, 10R*)-13S*-hydroxy-15, 16-dinorlabr-1(2)-en-3-one, and named tagals in $\mathrm{X}$.

The known compounds were identified as $\left(5 S^{*}, 8 S^{*}, 9 S^{*}, 10 R^{*}, 13 S^{*}\right)$-2-hydroxy-16-nor-3-oxodolabr1,4(18)-dien-15-oic acid (2) [8], (5S*, 8S*, 9S*, 10R*, 13S*)-3-hydroxy-16-nor-2-oxodolabr-3-en-15-oic acid (3) [8], tagalsin P (4) [8], tagalsin Q (5) [8] and (5S*, 8S*, 9S*, 10R*, 13S*)-3,16-dihydroxydolabr-3-ene-2,15dione (6) [8], respectively, on the basis of their ${ }^{1} \mathrm{H}$ NMR and ${ }^{13} \mathrm{C}$ NMR spectra analysis and comparison with those reported data in the related literatures (Figure 2). 


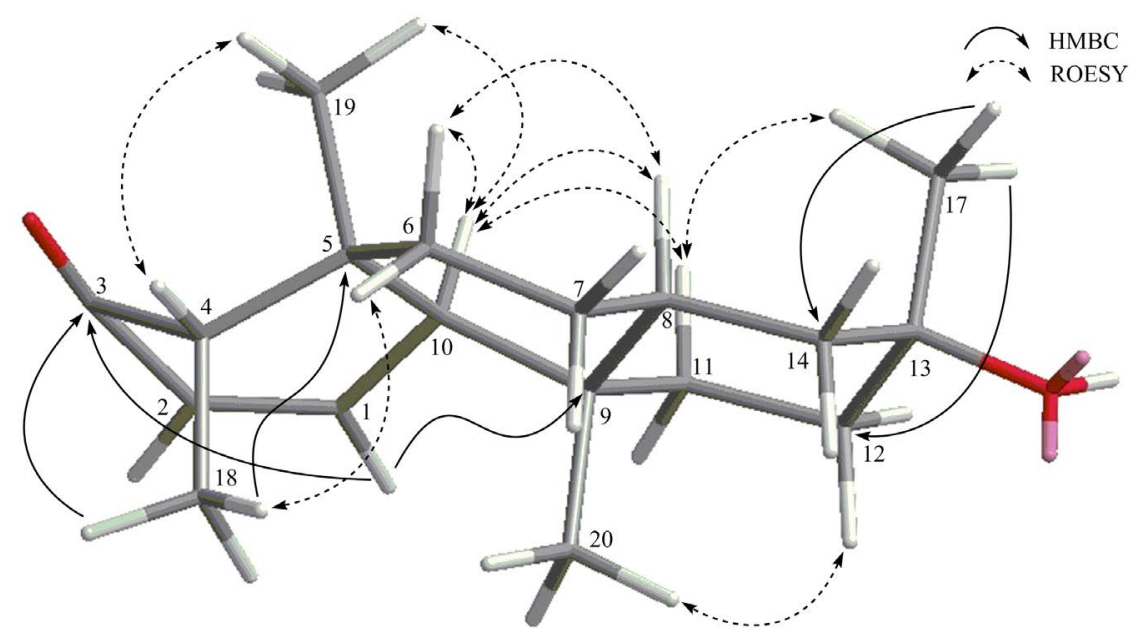

Figure 3.The key HMBC and ROESY correlations of compound 1.

Table 1. NMR data of compound 1 (at $500 \mathrm{MHz}$ in $\mathrm{CDCl}_{3}$, in $\mathrm{ppm}, \mathrm{J}$ in $\mathrm{Hz}$ ) ${ }^{\mathrm{a}, \mathrm{b}}$.

\begin{tabular}{|c|c|c|c|c|c|}
\hline Position & $\delta_{\mathrm{C}}$ & $\delta_{\mathrm{H}}(\mathrm{HSQC})$ & COSY & HMBC & ROESY \\
\hline 1 & $148.0 \mathrm{CH}$ & $6.84(\mathrm{dd}, 10.1,5.9)$ & $2 / 10$ & $3 / 10 / 9$ & $2 / 10 / 11 \alpha$ \\
\hline 2 & $130.2 \mathrm{CH}$ & $6.13(\mathrm{~d}, 10.2)$ & 1 & 10 & - \\
\hline 3 & $202.7 \mathrm{C}$ & - & - & - & - \\
\hline 4 & $45.0 \mathrm{CH}$ & $2.83(\mathrm{dd}, 13.3,6.6)$ & 18 & 3/5/18/19 & $18 / 19$ \\
\hline 5 & $39.0 \mathrm{C}$ & - & - & - & - \\
\hline 6 & $37.5 \mathrm{CH}_{2}$ & $\begin{array}{l}1.96(\alpha) \\
1.25(\beta)\end{array}$ & $6 / 7$ & $5 / 7 / 8 / 10$ & $\begin{array}{c}18 \\
8 / 10\end{array}$ \\
\hline 7 & $25.3 \mathrm{CH}_{2}$ & $\begin{array}{l}1.22(\alpha) \\
1.36(\beta)\end{array}$ & - & - & - \\
\hline 8 & $44.5 \mathrm{CH}$ & 1.31 & - & $13 / 14 / 20$ & $6 \beta / 10 / 14 \beta$ \\
\hline 9 & $39.3 \mathrm{C}$ & - & - & - & - \\
\hline 10 & $57.4 \mathrm{CH}$ & $1.86(\mathrm{~d}, 5.5)$ & 1 & $1 / 2 / 4 / 5 / 19 / 20$ & $6 \beta / 8 / 11 \beta / 19$ \\
\hline 11 & $37.4 \mathrm{CH}_{2}$ & $\begin{array}{l}1.72(\alpha) \\
1.25(\beta)\end{array}$ & $11 / 12$ & $\begin{array}{c}13 / 20 \\
8 / 10 / 12 / 13 / 20\end{array}$ & $\begin{array}{c}- \\
10 / 17\end{array}$ \\
\hline 12 & $35.5 \mathrm{CH}_{2}$ & $\begin{array}{l}1.69(\alpha) \\
1.58(\beta)\end{array}$ & $11 / 12$ & $11 / 13 / 17$ & $\begin{array}{c}20 \\
11 \beta\end{array}$ \\
\hline 13 & $71.2 \mathrm{C}$ & - & - & - & - \\
\hline 14 & $42.9 \mathrm{CH}_{2}$ & $\begin{array}{l}1.53(\mathrm{~d}, 13)(\alpha) \\
1.43(\mathrm{~d}, 13)(\beta)\end{array}$ & 8 & $\begin{array}{c}\text { 8/9/13/17 } \\
8 / 9 / 12 / 13 / 17\end{array}$ & $\begin{array}{c}20 / 7 \alpha \\
-\end{array}$ \\
\hline 17 & $26.9 \mathrm{CH}_{3}$ & $1.31(\mathrm{~s})$ & - & $12 / 13 / 14$ & $11 \beta$ \\
\hline 18 & 7.9 $9 \mathrm{CH}_{3}$ & $1.03(\mathrm{~d}, 5.2)$ & 4 & $3 / 4 / 5$ & $6 a$ \\
\hline 19 & $26.3 \mathrm{CH}_{3}$ & $0.87(\mathrm{~s})$ & - & $4 / 6 / 10$ & $4 / 6 a$ \\
\hline 20 & $13.5 \mathrm{CH}_{3}$ & $0.92(\mathrm{~s})$ & - & $10 / 8 / 11$ & $14 a$ \\
\hline
\end{tabular}

${ }^{\mathrm{a}}$ Assignments were established by interpretation of the ${ }^{1} \mathrm{H}-{ }^{1} \mathrm{H}$ COSY, HSQC, and HMBC spectra; ${ }^{\mathrm{b}}$ Overlapped signals are reported without designating multiplicity.

\subsection{Cytotoxicity Activity in Vitro}

As can be seem from Table 2, compound 2 showed significant cytotoxicity against CNE-2, A549, HepG2 andHCT-116 cell lines with $\mathrm{IC}_{50}$ values of $13.57 \pm 1.02$, $42.32 \pm 2.21,11.21 \pm 1.13$ and $15.23 \pm 1.42 \mu \mathrm{M}$, respectively, while the other five analogues had no obvious effect even with the concentration of $50 \mu \mathrm{M}$. 
Table 2. Cytotoxicity of compounds 1-6 against four cancer cell lines ${ }^{\mathrm{a}}$.

\begin{tabular}{|c|c|c|c|c|}
\hline \multirow{2}{*}{ Position } & \multicolumn{4}{|c|}{$\mathrm{IC}_{50} \mu \mathrm{M}^{\mathrm{a}}$} \\
\hline & CNE-2 & A549 & HepG2 & НCТ-116 \\
\hline 1 & $>50$ & $>50$ & $>50$ & $>50$ \\
\hline 2 & $13.57 \pm 1.02$ & $42.32 \pm 2.21$ & $11.21 \pm 1.13$ & $15.23 \pm 1.42$ \\
\hline 3 & $>50$ & $>50$ & $>50$ & $>50$ \\
\hline 4 & $>50$ & $>50$ & $>50$ & $>50$ \\
\hline 5 & $>50$ & $>50$ & $>50$ & $>50$ \\
\hline 6 & $>50$ & $>50$ & $>50$ & $>50$ \\
\hline Doxorubicin $^{\mathrm{b}}$ & $0.52 \pm 0.13$ & $3.12 \pm 0.23$ & $0.83 \pm 0.22$ & $0.42 \pm 0.11$ \\
\hline
\end{tabular}

${ }^{\mathrm{a}}$ All results are expressed as mean $\pm \mathrm{SD}, \mathrm{n}=3$ for each group; ${ }^{\mathrm{b}}$ Positive control.

\subsection{Discussion}

Up to now, chemical examinations of the plant Ceriops tagal have resulted in the isolation of 27 dolabrane-type diterpenes [3] [9], which could be divided into four sub-types: diterpene (twenty), 16-norditerpene (three), 15, 16-dinorditerpene (two) and ring A-seco-diterpene (two). Interestingly, dolabranes were regarded as a small group of natural products as there were only about fifty dolabranes isolated from plants, and as this papermentioned, most of them existed in Ceriops tagal. So we regarded dolabrane as chemoaxonomic marker of Ceriops tagal.

\section{Conclusion}

The present study attempts to explore the chemical constituents of the leaves of Ceriops tagal, and their cytotoxicity against four human carcinoma cell lines (CNE-2, HCT-116, HepG2 and A549). The result indicated that a new dolabrane dinorditerpene, tagalsine $\mathrm{X}$, and five known analogues were isolated and identified. Among them, only compound 2 had significant cytotoxicity against the tested cell lines with IC50 values ranging from 11.21 to $42.32 \mu \mathrm{M}$, which deserved further studies on its exact mechanisms.

\section{Acknowledgements}

This work was supported by the National Natural Science Foundation of China (81503226) and the 863 Program (2013AA092902).

\section{References}

[1] Lin, P. and Fu, Q. (1995) Environmental Ecology and Economic Utilization of Mangroves in China. Higher Education Press, Beijing, 1-95.

[2] Bamroongrugsa, N. (1999) Bioactive Substances from Mangrove Resources. Songklanakarin Journal of Science and Technology, 21, 377-386.

[3] Wang, H., Li, M.Y. and Wu, J. (2012) Chemical Constituents and Some Biological Activities of Plants from the Genus Ceriops. Chemistry \& Biodiversity, 9, 1-11. http://dx.doi.org/10.1002/cbdv.201000299

[4] Chen, J.D., Feng, D.Q., Yang, Z.W., Wang, Z.C., Qiu, Y. and Lin, Y.M. (2008) Antifouling Metabolites from the Mangrove Plant Ceriops Tagal. Molecules, 13, 212-219. http://dx.doi.org/10.3390/molecules13020212

[5] Du, S.S., Wang, C.F., Li, J., Zhang, H.M., Liu, Q.Z., Liu, Z.L. and Deng, Z.W. (2011) Antifeedant Diterpenoids against Tribolium castaneum from the Stems and Twigs of Ceriops tagal (Rhizophoraceae). Molecules, 16, 6060-6067. http://dx.doi.org/10.3390/molecules16076060

[6] Ouyang, X.W., Wang, X.C., Yue, Q.X. and Hu, L.H. (2010) A New Dolabrane-Type Diterpene from Ceriops tagal. Natural Product Communication, 5, 9-12.

[7] Wu, X., Liao, H.B., Zhu, X.H., Lu, H.Y., Zeng, X.B., Cui, L., Lv, X.H., Li, Y.Q. and Zhang, C.H. (2016) Two New Dammarane Triterpenes from the Leaves of Ceriops tagal. Records of Natural Products, 10, 628-632. 
[8] Hu, W.M., Li, M.Y., Li, J., Xiao, Q., Feng, G. and Wu, J. (2010) Dolabranes from the Chinese Mangrove, Ceriops tagal. Journal of Natural Products, 73, 1701-1705. http://dx.doi.org/10.1021/np100484w

[9] Yang, Y., Zhang, Y., Liu, D., Li-Weber, M., Shao, B. and Lin, W. (2015) Dolabrane-Type Diterpenes from the Mangrove Plant Ceriops tagal with Antitumor Activities. Fitoterapia, 103, 277-282.

http://dx.doi.org/10.1016/j.fitote.2015.04.016

Submit or recommend next manuscript to OALib Journal and we will provide best service for you:

- Publication frequency: Monthly

- 9 subject areas of science, technology and medicine

- Fair and rigorous peer-review system

- Fast publication process

- Article promotion in various social networking sites (LinkedIn, Facebook, Twitter, etc.)

- Maximum dissemination of your research work

Submit Your Paper Online: Click Here to Submit

Contact Us: service@oalib.com 